\title{
Renal response to frusemide in preterm infants with respiratory distress syndrome during the first three postnatal days
}

\author{
T F YEH, D RAVAL, E JOHN, AND R S PILDES
}

Division of Neonatology, Cook County Children's Hospital, and the University of Illinois, College of Medicine, USA

SUMMARY The renal effects of frusemide treatment in infants with respiratory distress syndrome shortly after birth and during the first three postnatal days were evaluated. Eighty five infants were randomly assigned to two groups. Forty two received three doses of intravenous frusemide $(1 \mathrm{mg} / \mathrm{kg})$ starting at age, mean (SD) $7 \cdot 5(4 \cdot 1)$ hours and given at approximately 24 hour intervals. Forty three control infants were treated similarly but were not given frusemide. The groups were comparable in birthweight, gestational age, and Apgar score and in pulmonary status, blood gases, serum electrolytes, and postnatal age.

Infants who received frusemide had significantly higher fractional excretion of sodium and chloride at 12 to 24,24 to 48 , and 48 to 72 hours, and higher calcium excretion at 24 to 48 and 48 to 72 hours after entry into the study than control infants. The study group had a significantly higher urine output and greater weight loss than the control group at 48 to 72 hours after entry into the study. There was no significant difference between groups in serum sodium, potassium, and calcium and in fractional excretion of potassium and the glomerular filtration rate. Infants with an Apgar score of more than 3 had higher urine output and had a better diuretic response to frusemide than those with a lower score. The results suggest that perinatal hypoxia may play an important role in renal function and in diuretic response to frusemide shortly after birth and early in the postnatal life of infants with respiratory distress syndrome.

Frusemide has been used in neonates with respiratory distress syndrome at various postnatal ages with conflicting results, ${ }^{12}$ but our previous controlled study indicated that very early use of this drug is beneficial. ${ }^{3}$ Although the effectiveness of frusemide on fluid and eletrolytes balance has been well documented in slightly older infants, this information is lacking in neonates. In preterm infants with respiratory distress syndrome, many of the humoral factors, for example aldosterone and vasopressin concentrations, may be increased ${ }^{45}$ shortly after birth and their renal response to frusemide may be altered. The present study was conducted to evaluate the renal effects of frusemide shortly after birth and during the first three postnatal days in infants with respiratory distress syndrome.

\section{Materials and methods}

The study was approved by the Scientific and Lay
Committees of this hospital and informed consent was obtained in each case. During a period of two years, renal function tests, serum and urinary electrolytes, and osmolality were assessed in 85 infants who met the following study criteria: (1) birthweight $2000 \mathrm{~g}$, or less; (2) presence of respiratory distress syndrome; and (3) normal cardiovascular status shown by normal blood pressure and capillary filling. The infants were randomly assigned to two groups: the first consisted of 42 infants who received three intravenous doses of frusemide (1 $\mathrm{mg} / \mathrm{kg}$ ) at approximately 24 hour intervals; the second consisted of 43 infants who were treated similarly but were not given frusemide. The study was started within 8 hours of birth, once the infant's condition had stabilised after admission to the neonatal intensive care unit.

The diagnosis of respiratory distress syndrome was based on clinical and radiological evidence reported previously. ${ }^{6}$ The clinical severity of res- 
piratory distress was assessed using the clinical respiratory distress score (RDS score) of Downes $\boldsymbol{e t}$ al. ${ }^{7}$ Blood gas samples were obtained before the study and subsequently every four to six hours as required from an umbilical arterial catheter or from a radial artery. Occasionally the blood gas samples were obtained by arterial capillary method; in these cases, only $\mathrm{pH}$ and $\mathrm{PCO}_{2}$ were included for data analysis. The $\mathrm{Po}_{2}$ values of these infants were obtained by transcutaneous method $\left(\mathrm{TcPo}_{2}\right)$ (Radiometer Copenhagen TCM transcutaneous monitor). The management of respiratory distress syndrome followed a standard protocol previously reported. ${ }^{6}$

During the study period fluid intake was adjusted to 80,95 , and $110 \mathrm{ml} / \mathrm{kg}$ per day on the first, second, and third postnatal days respectively. An additional $20 \mathrm{ml} / \mathrm{kg}$ per day was given if the infants were receiving phototherapy. The intravenous fluids consisted of a 5 to $10 \%$ dextrose with sodium (25 $\mathrm{mmol} / \mathrm{l})$, potassium $(20 \mathrm{mmol} / \mathrm{l})$, and calcium (200 $\mathrm{mg} / \mathrm{kg}$ per day calcium gluconate). No oral or nasogastric feeding was administered during the study period.

Using the $U$ bags (Hollister, Chicago), urine collections were obtained for osmolality and electrolytes analyses in four aliquots; 0 to 12,12 to 24,24 to 48 , and 48 to 72 hours after entry into study. Suprapubic compression was performed at the beginning and end of each collection to make sure that the bladder was empty. During the study, all infants were kept inside their incubators and their skin temperatures were maintained by servocontrol at $36 \cdot 5^{\circ} \mathrm{C}$.

Serum and urinary sodium and potassium concentrations were determined with a flame spectrophotometer, serum and urinary chloride concentrations with a chloridometer, serum blood urea nitrogen (BUN) by enzymatic conductivity with a Beckman BUN Analyzer, and serum and urinary creatinine by the Jaffe alkaline picrate method. Osmolality of serum and urine were determined by the freezing point method with an osmometer (Advanced Digimatic Osmometer, Model 3D II).

The following indices were determined: (1) creatinine clearance corrected for surface area according to the formula of Haycock et al $;^{8}$ (2) fractional excretion of filtered sodium $\left(\mathrm{FE}_{\mathrm{Na}}\right)$, chloride $\left(\mathrm{FE}_{\mathrm{Cl}}\right)$, and potassium $\left(\mathrm{FE}_{\mathrm{K}}\right)$ using the conventional formula; eg $\mathrm{FE}_{\mathrm{Na}}=(\mathrm{U} / \mathrm{S} \mathrm{Na}) /(\mathrm{U} / \mathrm{S} \mathrm{Cr}) \times 100$; where $\mathrm{U} / \mathrm{S} \quad \mathrm{Na}=$ urinary sodium $(\mathrm{mmol} / \mathrm{l}) /$ serum sodium $(\mathrm{mmol} / \mathrm{l})$, and $\mathrm{U} / \mathrm{S} \mathrm{Cr}=$ urinary creatinine $(\mathrm{mmol} / \mathrm{l}) / \mathrm{serum}$ creatinine $(\mathrm{mmol} / \mathrm{l})$; (3) osmolar clearance $\left(\mathrm{C}_{\mathrm{osm}}\right)$ using the equation

$$
\mathrm{C}_{\mathrm{osm}}=\frac{\mathrm{U}_{\mathrm{osm}} \cdot \mathrm{V}}{\mathrm{P}_{\mathrm{osm}}}
$$

where $U_{o s m}=$ urine osmolality, $P_{o s m}=$ plasma osmolality and $\mathrm{V}=$ urine volume; (4) water clearance $\left(\mathrm{C}_{\mathrm{H}, \mathrm{O}}\right)$ using the formula $\mathrm{C}_{\mathrm{H}_{2} \mathrm{O}}=\mathrm{V}-\mathrm{C}_{\mathrm{osm}}$. Both osmolar and water clearance were expressed as $\mathrm{ml} / \mathrm{min}$ per $100 \mathrm{ml}$ glomerular filtration rate.

The data from the study periods were compared between the groups using independent Student's $t$ test and within the group using dependent Student's $t$ test. The $\chi^{2}$ test was used to compare the groups with respect to categorical variables. The values were expressed as mean (SD). Except where otherwise indicated the time specified in the text was the time or period after entry into the study.

\section{Results}

Pertinent clinical data for the two groups are shown in Table 1. There was no significant difference between the two groups in respect of gestational age, birthweight, and pulmonary status at the time of entry into the study. The postnatal age was $7 \cdot 2$ $(4 \cdot 0)$ hours for the control group and $7 \cdot 5(4 \cdot 1)$ hours for the study group. Tables 2 and 3 provide the data on all variables assessed during the study.

Serum electrolytes, blood urea nitrogen, creatinine, and osmolality (Table 2). The baseline values of serum electrolytes, blood urea nitrogen, creatinine, and osmolality were comparable between the groups. Both groups of infants had significant $(\mathrm{P}<0.01)$ increases in serum sodium from their baseline values by 24 hours after entry into the study, but there were no significant differences between the groups at any time during the study. Serum chloride increased in the control group at 24

Table 1 Perinatal information and pulmonary status of preterm infants with respiratory distress syndrome (RDS) treated (study group) and not treated (control group) with frusemide

\begin{tabular}{|c|c|c|}
\hline & $\begin{array}{l}\text { Control group } \\
(n=43)\end{array}$ & $\begin{array}{l}\text { Study group } \\
(n=42)\end{array}$ \\
\hline Birthweight (g), mean (SD) & $1297(323)$ & $1382(379)$ \\
\hline \multicolumn{2}{|l|}{ Apgar score at 1 minute } & $31.4(2.2)$ \\
\hline$\leqslant 3$ & 19 & 16 \\
\hline$>3$ & 24 & 26 \\
\hline \multicolumn{3}{|l|}{ Type of delivery } \\
\hline Vaginal & 22 & 28 \\
\hline Caesarean & 21 & 14 \\
\hline \multicolumn{3}{|l|}{ Blood chemistry } \\
\hline $\mathrm{F}_{1} \mathrm{O}_{2}$ & $0.59(0.22)$ & $0.57(0.24)$ \\
\hline $\mathrm{Po}_{2}(\mathrm{kPa})$ & $11 \cdot 74(5 \cdot 7)$ & $10.4(6.7)$ \\
\hline$-\mathrm{PCO}_{2}(\mathrm{kPa})$ & $5.4(1.6)$ & $5.8(1.4)$ \\
\hline $\mathrm{pH}$ & $7 \cdot 27(0 \cdot 09)$ & $7 \cdot 25(0 \cdot 08)$ \\
\hline Assisted ventilation & 35 & 36 \\
\hline RDS score, mean (SD) & $7 \cdot 5(2 \cdot 7)$ & $7 \cdot 6(2 \cdot 7)$ \\
\hline
\end{tabular}

Conversion-SI to traditional units: $1 \mathrm{kPa} \approx 7.5 \mathrm{mmHg}$. 
Table 2 Changes in serum electrolytes, calcium, blood urea nitrogen $(B U N)$, creatinine and osmolality values in preterm infants with respiratory distress syndrome, treated (study), and not treated (control) with frusemide (values, mean $(S D))$

\begin{tabular}{|c|c|c|c|c|c|c|}
\hline & \multirow[t]{2}{*}{ Group } & \multirow{2}{*}{$\begin{array}{l}\text { Beginning of } \\
\text { study }\end{array}$} & \multicolumn{4}{|c|}{ Time after entry into study (hrs) } \\
\hline & & & 12 & 24 & 48 & 72 \\
\hline Sodium (mmol/l) & $\left\{\begin{array}{l}\text { Control } \\
\text { Study }\end{array}\right.$ & $\begin{array}{l}137.3(4 \cdot 6) \\
137.2(4 \cdot 0)\end{array}$ & $\begin{array}{l}138.8(6 \cdot 1) \\
137.9(3 \cdot 8)\end{array}$ & $\begin{array}{l}141.5(6 \cdot 8)^{+\dagger} \\
140.6(5.4)^{+\dagger}\end{array}$ & $\begin{array}{l}143.4(5.1) \dagger \dagger \\
141.9(6.4)+\dagger\end{array}$ & $\begin{array}{l}141 \cdot 8(4 \cdot 6) \dagger \dagger \\
141 \cdot 6(5 \cdot 5) \dagger \dagger\end{array}$ \\
\hline Chloride $(\mathrm{mmol} / \mathrm{l})$ & $\left\{\begin{array}{l}\text { Control } \\
\text { Study }\end{array}\right.$ & $\begin{array}{l}105 \cdot 5(5 \cdot 7) \\
104.6(4 \cdot 3)\end{array}$ & $\begin{array}{ll}106 \cdot 1 & (5 \cdot 5) \\
105 \cdot 3 & (4 \cdot 2)\end{array}$ & $\begin{array}{l}108 \cdot 5(5 \cdot 7)^{\dagger \dagger} \\
105 \cdot 3(4 \cdot 2)^{*}\end{array}$ & $\begin{array}{l}108.6(7 \cdot 4) \\
102.2(7 \cdot 0)^{* *}\end{array}$ & $\begin{array}{l}108.8(6.5) \dagger \dagger \\
103.8(6.9)^{* *}\end{array}$ \\
\hline Potassium (mmol/l) & $\left\{\begin{array}{l}\text { Control } \\
\text { Study }\end{array}\right.$ & $\begin{array}{l}6.9(1.6) \\
6.8(1.9)\end{array}$ & $\begin{array}{l}6 \cdot 7(1 \cdot 2) \\
7 \cdot 1(1 \cdot 7)\end{array}$ & $\begin{array}{l}6 \cdot 3(1 \cdot 1) \\
6 \cdot 7(1.6)\end{array}$ & $\begin{array}{l}6.4(1.3) \\
6 \cdot 5(1.0)\end{array}$ & $\begin{array}{l}6.4(0.9) \\
6.4(1.4)\end{array}$ \\
\hline Calcium (mmol/l) & $\left\{\begin{array}{l}\text { Control } \\
\text { Study }\end{array}\right.$ & $\begin{array}{l}1.9(0 \cdot 2) \\
2 \cdot 0(0 \cdot 2)\end{array}$ & $\begin{array}{l}1.9(0 \cdot 2) \\
2 \cdot 0(0 \cdot 2)\end{array}$ & $\begin{array}{l}1.9(0.2) \\
1.9(0.2)\end{array}$ & $\begin{array}{l}2 \cdot 2(0 \cdot 2) \\
2 \cdot 1(0 \cdot 2)\end{array}$ & $\begin{array}{l}2 \cdot 2(0 \cdot 1) \\
2 \cdot 2(0 \cdot 1)\end{array}$ \\
\hline BUN (mmol/l) & $\left\{\begin{array}{l}\text { Control } \\
\text { Study }\end{array}\right.$ & $\begin{array}{l}3.4(1.8) \\
3.6(1.8)\end{array}$ & $\begin{array}{l}5 \cdot 5(2 \cdot 2) \dagger \\
5 \cdot 7(2 \cdot 0) \dagger\end{array}$ & $\begin{array}{l}6 \cdot 6(2 \cdot 5) \\
7 \cdot 0(2 \cdot 5) \dagger\end{array}$ & $\begin{array}{l}6.5(2.9) \dagger \\
7.6(2 \cdot 6) \dagger\end{array}$ & $\begin{array}{l}5 \cdot 8(3 \cdot 6) \dagger \\
7 \cdot 2(2 \cdot 9) \dagger\end{array}$ \\
\hline Osmolality $(\mathrm{mmol} / \mathrm{kg})$ & $\left\{\begin{array}{l}\text { Control } \\
\text { Study }\end{array}\right.$ & $\begin{array}{l}285 \cdot 6(20 \cdot 9) \\
285 \cdot 1(9 \cdot 0)\end{array}$ & $\begin{array}{l}289.4(9.2) \\
290.3(8.9)\end{array}$ & $\begin{array}{l}296 \cdot 3(13.9) \dagger \\
296 \cdot 1(17 \cdot 2) \dagger\end{array}$ & $\begin{array}{l}298.2(11.7) \dagger \\
299.3(13 \cdot 1) \dagger\end{array}$ & $\begin{array}{l}297.9(15 \cdot 2) \dagger \\
300 \cdot 2(10 \cdot 7) \dagger\end{array}$ \\
\hline Creatinine $(\mu \mathrm{mol} / \mathrm{l})$ & $\left\{\begin{array}{l}\text { Control } \\
\text { Study }\end{array}\right.$ & $\begin{array}{l}80.4(44.2) \\
83.9(25 \cdot 6)\end{array}$ & $\begin{array}{r}93.7(15 \cdot 9) \\
104 \cdot 3(21 \cdot 2)\end{array}$ & $\begin{array}{c}99.9(15.91) \\
110.5(22.9)^{*}+\end{array}$ & $\begin{array}{c}96.4(18.6) \\
117.6(25.6)^{*} \dagger\end{array}$ & $\begin{aligned} 93.7 & (25.6) \\
115.8 & (24.7)^{*} \dagger\end{aligned}$ \\
\hline
\end{tabular}

${ }^{*} \mathrm{P}<0.05 ;{ }^{* *} \mathrm{P}<0.01$ (independent $t$ test); $+\mathrm{P}<0.05 ;++\mathrm{P}<0.01$ (dependent $t$ test).

Indicates significance when comparison performed within the group, with the baseline values.

*Indicates significance between the groups.

Conversion-SI to traditional units: calcium $1 \mathrm{mmol} / \approx \approx 4 \mathrm{mg} / 100 \mathrm{ml} ; \mathrm{BUN} 1 \mathrm{mmol} / \mathrm{l} \approx 2 \cdot 8 \mathrm{mg} / 100 \mathrm{ml}$; $\mathrm{creatinine} 1 \mu \mathrm{mol} / \mathrm{l} \approx 0 \cdot 01 \mathrm{mg} / 100 \mathrm{ml}$.

Table 3 Changes in urine output, glomerular filtration rate (GFR), fractional excretion of electrolytes, osmolar clearance, and free water clearance in study and control infants (values, mean (SD))

\begin{tabular}{|c|c|c|c|c|c|}
\hline & \multirow[t]{2}{*}{ Group } & \multicolumn{4}{|c|}{ Time after entry into study (hrs) } \\
\hline & & $0-12$ & $12-24$ & 2448 & $48-72$ \\
\hline $\begin{array}{l}\text { Urine outputl) } \\
(\mathrm{m} / \mathrm{kg} \text { per } \mathrm{hr})\end{array}$ & $\left\{\begin{array}{l}\text { Control } \\
\text { Study }\end{array}\right.$ & $\begin{array}{l}1.7(1.0) \\
1.8(1.1)\end{array}$ & $\begin{array}{l}2 \cdot 1(1 \cdot 1) \\
2 \cdot 4(1 \cdot 4)\end{array}$ & $\begin{array}{l}2.1(1.0) \\
2.5(1.4) \dagger\end{array}$ & $\begin{array}{l}2.3(1.2) \dagger \\
2.9(1.3)^{* \dagger}\end{array}$ \\
\hline $\begin{array}{l}\text { GFR } \\
\left(\mathrm{ml} / \min \text { per } 1.73 \mathrm{~m}^{2}\right)\end{array}$ & $\left\{\begin{array}{l}\text { Control } \\
\text { Study }\end{array}\right.$ & $\begin{array}{l}5 \cdot 2(3 \cdot 1) \\
4 \cdot 2(3 \cdot 0)\end{array}$ & $\begin{array}{l}6 \cdot 4(4 \cdot 8) \\
6 \cdot 2(3 \cdot 7)\end{array}$ & $\begin{array}{l}6.7(3 \cdot 7) \dagger \\
6.9(4 \cdot 1) \dagger\end{array}$ & $\begin{array}{l}7 \cdot 0(4 \cdot 2) \dagger \\
7 \cdot 4(4 \cdot 7) \dagger\end{array}$ \\
\hline Sodium excretion (\%) & $\left\{\begin{array}{l}\text { Control } \\
\text { Study }\end{array}\right.$ & $\begin{array}{l}2 \cdot 3(1 \cdot 9) \\
6 \cdot 3(4 \cdot 8)^{* *}\end{array}$ & $\begin{array}{l}3 \cdot 2(2 \cdot 6) \dagger \\
5 \cdot 0(3 \cdot 0)^{* * *}\end{array}$ & $\begin{array}{l}3 \cdot 9(2 \cdot 8) \dagger \\
6 \cdot 1(4 \cdot 5)^{* *}\end{array}$ & $\begin{array}{l}4 \cdot 0(2 \cdot 6) \dagger \dagger \\
7 \cdot 3(4 \cdot 2)^{* *}\end{array}$ \\
\hline Chloride excretion (\%) & $\left\{\begin{array}{l}\text { Control } \\
\text { Study }\end{array}\right.$ & $\begin{array}{l}2.4(2.4) \\
7 \cdot 2(6.9)^{* *}\end{array}$ & $\begin{array}{l}2.5(3.4) \\
5.5(3.9)^{* *}\end{array}$ & $\begin{array}{l}2 \cdot 8(2 \cdot 5) \\
5 \cdot 5(4 \cdot 7)^{* *}\end{array}$ & $\begin{array}{l}3.2(2 \cdot 6) \\
7.7(5 \cdot 5)^{* *}\end{array}$ \\
\hline Potassium excretion (\%) & $\left\{\begin{array}{l}\text { Control } \\
\text { Study }\end{array}\right.$ & $\begin{array}{l}38.9(17.4) \\
42.5(18 \cdot 8)\end{array}$ & $\begin{array}{l}46 \cdot 0(20.9) \\
51.7(22 \cdot 8)\end{array}$ & $\begin{array}{l}40.5(21.9) \\
46.9(27.7)\end{array}$ & $\begin{array}{l}41 \cdot 2(23 \cdot 6) \\
45.9(17 \cdot 6)\end{array}$ \\
\hline $\begin{array}{l}\text { Osmolar clearance } \\
(\mathrm{mV} / \mathrm{min} \text { per } 100 \mathrm{GFR})\end{array}$ & $\left\{\begin{array}{l}\text { Control } \\
\text { Study }\end{array}\right.$ & $\begin{array}{l}5 \cdot 0(3 \cdot 1) \\
8 \cdot 7(6 \cdot 2)^{*}\end{array}$ & $\begin{array}{l}5 \cdot 7(3 \cdot 5) \\
8 \cdot 3(5 \cdot 2)^{*}\end{array}$ & $\begin{array}{l}6 \cdot 7(4 \cdot 0) \dagger \\
7 \cdot 7(3 \cdot 8)\end{array}$ & $\begin{array}{l}7 \cdot 0(5 \cdot 7) \dagger \\
7 \cdot 2(4 \cdot 8)\end{array}$ \\
\hline $\begin{array}{l}\text { Free water clearance } \\
(\mathrm{m} / \mathrm{min} \text { per } 100 \mathrm{GFR})\end{array}$ & $\left\{\begin{array}{l}\text { Control } \\
\text { Study }\end{array}\right.$ & $\begin{array}{l}3 \cdot 1(4 \cdot 0) \\
3 \cdot 3(3 \cdot 0)\end{array}$ & $\begin{array}{l}2 \cdot 6(3 \cdot 2) \\
3 \cdot 4(4 \cdot 0)\end{array}$ & $\begin{array}{l}2 \cdot 5(3 \cdot 0) \\
3 \cdot 2(4 \cdot 0)\end{array}$ & $\begin{array}{l}2.6(3 \cdot 1) \\
3 \cdot 0(3 \cdot 3)\end{array}$ \\
\hline
\end{tabular}

${ }^{*} \mathrm{P}<0.05 ;{ }^{* *} \mathrm{P}<0.01$ (independent $t$ test); $+\mathrm{P}<0 \cdot 05 ;++\mathrm{P}<0 \cdot 01$ (dependent $t$ test).

tIndicates significance when comparison performed within the group, with the baseline values.

*Indicates significance between the groups.

and 72 hours but remained unchanged in the study group. A significant difference in serum chloride between the groups was seen at 24,48 , and 72 hours. The serum potassium remained unchanged in both groups and did not show any significant difference between the groups during the study.

Both groups of infants had significant increases in serum blood urea nitrogen and osmolality but no significant difference was seen between the groups at any time during the study. While there was no significant change in serum creatinine in the control group, significant increases were seen in the study group at 24,48 , and 72 hours and these were higher than the respective values of the control infants.

Glomerular filtration rate, urine output (Table 3), and body weight changes. Both groups had significant increases in glomerular filtration rate at 24 to 48 and 48 to 72 hours. No significant difference was seen, however, between the groups during the 
study. A significant increase in urine output was seen at 24 to 48 and 48 to 72 hours in the study group, while in the control group this was seen only at 48 to 72 hours. The urine output was significantly higher in the frusemide group than in the control group at 48 to 72 hours.

Both groups of infants lost weight during the study $(1.7 \%, 5.4 \%, 8.3 \%$ of birthweight in the control and $2.5 \%, 6 \cdot 6 \%$, and $10.3 \%$ of birthweight in the study group at 24,48 , and 72 hours respectively) but a statistically significant difference between the groups was seen only at 72 hours.

Fractional excretion of filtered electrolytes (Table 3 ). The baseline values of $\mathrm{FE}_{\mathrm{Na}}, \mathrm{FE}_{\mathrm{C} 1}$ at 0 to 12 hours in the frusemide group were already higher than in the control group; they remained unchanged and were higher than in the control group throughout the study period. Significant increases in $\mathrm{FE}_{\mathrm{Na}}$ from the baseline were also seen in the control infants at 12 to 24,24 to 48 , and 48 to 72 hours. The urinary $\mathrm{FE}_{\mathrm{K}}$ was higher in the study group than in the control group but the differences between the groups failed to reach a statistical significance.

Osmolar and free water clearance. (Table 3). The values of osmolar clearance at 0 to 12 and 12 to 24 hours in the study group were higher than in the controls. In the control group, a significant increase in osmolar clearance was seen at 24 to 48 and 48 to 72 hours; their values were comparable to those of the study group. The free water clearance remained unchanged in both groups and did not show any significant difference between the groups during the study.

Serum and urinary calcium concentrations. Based on the data obtained from 32 infants (17 control, 15 study), in which serum and urinary calcium were measured, infants in the study group had significantly $(\mathrm{P}<0.05)$ higher calcium excretion than infants in the control group at 24 to 48 hours $(0.37$ $(0.05) \mathrm{mmol} / \mathrm{l} v 0.15(0.07) \mathrm{mmol} / \mathrm{l})$ and 48 to 72 hours $(0.6(0.1) \mathrm{mmol} / \mathrm{l} v 0.2(0.12) \mathrm{mmol} / \mathrm{l})$ after entry into study. There was, however, no significant difference between groups' serum calcium concentrations at any time during the study. (Table 2).

Perinatal hypoxia and renal response to frusemide. Since perinatal hypoxia may play an important role in renal function and renal response to frusemide, the infants were divided into two groups based on their Apgar scores measured one minute after birth. The data were analysed and the statistical significances between the groups are shown in Table 4 . The results can be summarised as follows: (1) within the study group, infants with an Apgar score greater than 3 had better diuretic response than those whose scores was 3 or less; (2) in the control group, infants with an Apgar score of greater than 3 had higher urine output and a higher glomerular filtration rate than infants whose score was 3 or less at 48 to 72 hours after entry into study; (3) for those infants

Table 4 Statistics comparisons of urine output (U/O), fractional sodium excretion $\left(F E_{N a}\right)$, and glomerular filtration rate (GFR), in relation to Apgar score in preterm infants with respiratory distress syndrome treated (study) and not treated (control) with frusemide

\begin{tabular}{|c|c|c|c|c|c|}
\hline & & \multicolumn{4}{|c|}{ Time after entry into study } \\
\hline & & $0-12$ & $12-24$ & $24-48$ & $48-72$ \\
\hline Study group & $\mathrm{U} / \mathrm{O}$ & $<0.05^{*}$ & $<0.01$ & $<0.01$ & ns \\
\hline Apgar score $>3(26)$ & $\mathrm{FE}_{\mathrm{Na}}$ & $<0.05$ & ns & ns & ns \\
\hline Apgar score $\leqslant 3(16)$ & GFR & ns & ns & ns & ns \\
\hline $\begin{array}{l}\text { Control group } \\
\text { Apgar score }>3 \text { (24) } \\
v\end{array}$ & $\begin{array}{l}\mathrm{U} / \mathrm{O} \\
\mathrm{FE}_{\mathrm{Na}}\end{array}$ & $\begin{array}{l}\text { ns } \\
\text { ns }\end{array}$ & $\begin{array}{l}\text { ns } \\
\text { ns }\end{array}$ & $\begin{array}{l}\text { ns } \\
\text { ns }\end{array}$ & $\begin{array}{l}<0 \cdot 01 \\
\mathrm{~ns}\end{array}$ \\
\hline Apgar score $\leqslant 3(19)$ & GFR & ns & ns & ns & $<0.05$ \\
\hline $\begin{array}{l}\text { Apgar score }>3 \\
\text { Control }(24) \\
v\end{array}$ & $\begin{array}{l}\mathrm{U} / \mathrm{O} \\
\mathrm{FE}_{\mathrm{Na}}\end{array}$ & $\begin{array}{l}\text { ns } \\
<0.01\end{array}$ & $\begin{array}{l}\text { ns } \\
<0 \cdot 01\end{array}$ & $\begin{array}{l}<0 \cdot 05 \\
<0 \cdot 01\end{array}$ & $\begin{array}{l}<0 \cdot 05 \\
<0 \cdot 01\end{array}$ \\
\hline Study (26) & GFR & ns & ns & ns & ns \\
\hline $\begin{array}{l}\text { Apgar score } \leqslant 3 \\
\text { Control (19) } \\
v\end{array}$ & $\begin{array}{l}\mathrm{U} / \mathrm{O} \\
\mathrm{FE}_{\mathrm{Na}}\end{array}$ & $\begin{array}{l}\text { ns } \\
<0.05\end{array}$ & $\begin{array}{l}\text { ns } \\
\text { ns }\end{array}$ & $\begin{array}{l}\text { ns } \\
\text { ns }\end{array}$ & $\begin{array}{l}\text { ns } \\
<0.01\end{array}$ \\
\hline Study (16) & GFR & ns & ns & ns & ns \\
\hline
\end{tabular}

*P value (independent Student's $t$ test)

ns = not significant (individual data available upon request).

All the significance values indicated show that study group infants or those with Apgar scores greater than 3 , or both, had a greater urine output, fractional sodium excretion, and glomerular filtration rate than control infants or those with an Apgar score of 3 or less. 
with an Apgar score greater than 3, frusemide significantly enhanced the urine output and sodium excretion compared with control infants; (4) for those infants with Apgar score of 3 or less, frusemide did not enhance urine output, but it did, to some extent, enhance sodium excretion compared with control infants. From these data it seems that: (1) perinatal hypoxia not only affects the urine output in the control infants but also affects the diuretic response to frusemide in the treated infants; (2) perinatal hypoxia has little effect on sodium excretion in the control infants and on natriuretic response in the study group.

\section{Discussion}

This study indicates that a spontaneous increase in urine output occurred at 48 to 72 hours and in urinary sodium and chloride excretion at 12 to 24,24 to 48 , and 48 to 72 hours after entry into the study $(7.2(4.0)$ hours postnatal age) in infants with respiratory distress syndrome. The use of frusemide enhances sodium and chloride excretion at 0 to 12,12 to 24,24 to 48 , and 48 to 72 hours and urine output at 24 to 48 and 48 to 72 hours after beginning treatment $(7 \cdot 5(4 \cdot 1)$ hours $)$. The inadequate diuretic response to frusemide within 24 hours of frusemide treatment may be related to perinatal hypoxia.

Frusemide has been the diuretic of choice in newborn infants. This drug inhibits active chloride reabsorption from the ascending limb of the loop of Henle, resulting in a decrease in passive sodium reabsorbtion and diuresis. ${ }^{9}$ Frusemide stimulates the renal synthesis of prostaglandins, particularly prostaglandin $E_{2}$, which may mediate the haemodynamic and tubular effects of the kidney. ${ }^{10} 11$ Frusemide has also been shown to have an antivasopressin effect on the distal tubules. ${ }^{12}$ In addition, frusemide produces systemic vascular effects that are independent of its diuretic action. ${ }^{13} 14$ Several studies carried out in the late neonatal period showed that frusemide produced increases in urine flow rates and sodium, potassium, and calcium excretion. $^{215}$ The effects of frusemide on fluid and electrolytes balance have not been well studied in critically ill preterm infants shortly after birth. Infants with respiratory distress syndrome have raised renin, angiotensin, aldosterone, and circulatory prostaglandins values early in their postnatal life $\mathrm{e}^{16-18}$ that may affect the fluid and electrolyte balance during frusemide treatment.

It is clear from this study that frusemide induces saluresis very early in postnatal life. This effect was observed even in infants with very low Apgar scores. It is also interesting to observe that, in spite of saluresis, the serum sodium concentration was raised in both groups of infants. This may indicate that an excessive water over electrolytes loss occurred during the study. Since there was no seeming increase in urine output in both groups early in the course of the study, this excessive water loss might be through routes other than renal excretion. It is well known that preterm infants with respiratory distress syndrome tend to have high insensible water loss, either through the respiratory tract or skin, particularly under phototherapy. Nearly half of the infants received phototherapy during the study. The extra fluid intake of $20 \mathrm{ml} / \mathrm{kg}$ per day to compensate for water loss from phototherapy may not be adequate.

We found a considerable increase in calcium excretion after frusemide which was consistent with the reports by Savage et al. ${ }^{2}$ The serum concentrations of calcium, however, were comparable between the groups indicating that an alteration in calcium homeostasis may occur after frusemide treatment. The long term effect of prolonged use of frusemide remains to be investigated further.

Contrary to what has been shown in previous studies performed in the late neonatal period, we did not observe a significant increase in urinary potassium excretion and hypokalaemia after frusemide administration. Urinary excretion of potassium is affected essentially by urine flow rate, mineral corticoids, urinary sodium excretion, and acid base balance. ${ }^{19}{ }^{20}$ Lack of appreciable kaliuresis in the first 72 hours in our patients is most probably due to a combination of factors: a low glomerular filtration rate, low urine flow rate, partial end organ insensitivity of distal tubule to aldosterone, decreased potassium permeability of distal tubular membrane, and immaturity of sodiumpotassium-adenosine triphosphate enzyme. ${ }^{20}$

It is not clear from this study why frusemide did not produce appreciable diuresis until 24 to 48 hours after medication. Hypoxia is a potent stimulus for vasopressin release, ${ }^{21}$ and newborns with hypoxia tend to have high circulating vasopressin. ${ }^{22}$ The diuretic effect of frusemide has been ascribed in part to stimulation of renal prostaglandins which in turn enhance water excretion by antagonising the effect of vasopressin on the distal and collecting tubule and by decreasing the medullary osmotic gradient by increasing the medullary blood flow. ${ }^{16}$ Thus, the diuretic effect of frusemide could be antagonised by vasopressin in hypoxia. Furthermore, the serum osmolality (Table 2) and urine osmolality (181 and $206 \mathrm{mmol} / \mathrm{kg}$ in the control and study groups respectively) were already high on the first postnatal day, indicating a degree of dehydration. While infants are dehydrated, vasopressin release may be stimulated and noticeable water 
diuresis may not occur. Since the diuretic response of frusemide depends on the fraction of the administered dose that reaches the renal tubule lumen, it is possible that the amount of frusemide in the tubule was not adequate because of a low glomerular filtration rate and low tubular secretion, both of which may occur during perinatal hypoxia. ${ }^{21}$ Alternatively, it is also possible that the dosage of frusemide was not adequate or the renal tubules were not sensitive to it because of immaturity. We did not measure the concentrations of frusemide in serum and urine and do not know if larger dosage would achieve diuresis. From this study, it seems that perinatal hypoxia and a low glomerular filtration rate are responsible for the lack of diuresis early in postnatal life.

In summary, this study indicates that small preterm infants with respiratory distress syndrome may not achieve a diuretic response to frusemide shortly after birth. Perinatal hypoxia and dehydration may be the important factors responsible for this lack of diuresis. Natriuresis and chloruresis occurred effectively shortly after frusemide administration and did not seem to be affected by perinatal hypoxia. The mechanisms remain unknown. The results of this study provide useful information for further investigation.

\section{References}

${ }^{1}$ Marks KH, Berman W, Friedman F, Whitman V, Lee C, Maisel MJ. Furosemide in hyaline membrane disease. Pediatrics 1978;62:785-8.

2 Savage MO, Wilkinson AR, Baum JD, Roberton NRC. Furosemide in respiratory distress syndrome. Arch Dis Child 1975;50:709-13.

3 Yeh TF, Shibli A, Leu ST, Admam M, Pildes RS. Furosemide therapy in premature infants $(\leq 2000 \mathrm{~g})$ with respiratory distress syndrome: a randomized controlled study. J Pediatr 1984; 105:603-9.

4 Rees L, Forsling ML, Brook CGD. Vasopressin concentrations in the neonatal period. Clin Endocrinol 1980;12:357-62.

5 Hoppenstein JM, Miltenberger FM, Moran WH. The increase in blood level of vasopressin in infants during birth and surgical procedures. Surg Gynecol Obstet 1968;127:966-74.

6 Yeh TF, Luken JA, Thalji A, Raval D, Carr I, Pildes RS. Intravenous indomethacin therapy in premature infants with persistent ductus arteriosus-a double blind study. J Pediatr 1981;98:137-45.
${ }^{7}$ Downes JJ, Vidyasagar D, Morrow GM III, Boggs TR. Respiratory distress syndrome of newborn infants I. New clinical scoring system (RDS score) with acid base and blood gas correlation. Clin Pediatr 1970;9:325-31.

${ }^{8}$ Haycock GG, Chir MB, Schwartz GJ, Wisotksy DH. Geometric method for measuring body surface area: a height-weight formula validated in infants, children and adults. $J$ Pediatr 1978;93:62-6.

${ }^{9}$ Morgan T, Tadokoro M, Martin D, Berliner RW. Effect of furosemide on $\mathrm{Na}^{+}$and $\mathrm{K}^{+}$transport studied by microperfusion of the rat nephron. Am J Physiol 1970;218:292-7.

${ }^{10}$ Patak RV, Fadem SZ, Rosenblatt SG, Lifschitz MD, Stein JH. Diuretic induced changes in renal blood flow and prostaglandins E excretion in the dog. Am J Physiol 1979;236:494-500.

1 Sulyok E, Varga F, Nemeth M, et al. Furosemide-induced alterations in the electrolyte status, the function of reninangiotensin-aldosterone system, and the urinary excretion of postaglandins in the newborn infant. Pediatr Res 1980;14: 765-8.

12 Anderson RJ, Berl T, McDonald KM, Schrier RW. Evidence for an in-vivo antagonism between vasopressin and prostaglandin in the mammalian kidney. $J$ Clin Invest 1975;56:420-6.

13 Dikshit K, Vyder JK, Forrester JS, Chatterjee K, Prakash R. Renal and extrarenal hemodynamic effects of furosemide in congestive heart failure after myocardial infarction. $N$ Engl $J$ Med 1973;288:1087-90.

14 Schuster CJ, Weil AM, Besso J, Carpio M, Henning RJ. Blood volume following diuresis induced by furosemide. $\mathrm{Am} \mathrm{J} \mathrm{Med}$ 1984;76:585-92.

15 Ross BS, Pollak A, Oh W. The pharmacologic effects of furosemide therapy on the low-birth-weight infant. J Pediatr 1978;92:149-52.

${ }^{16}$ Hadeed AH, Leake RD, Weitzman RE, Fisher DA. Possible mechanisms of high blood levels of vasopressin during the neonatal period. $J$ Pediatr 1975;94:805-8.

17 Siegler RL, Walker MB, Crouch RH, Christenson P, Jubiz W Plasma prostaglandin $\mathrm{E}$ concentrations from birth through childhood. J Pediatr 1977;91:734-7.

${ }^{18}$ Sulyok E, Nemeth M, Tenyi I, et al. Postnatal development of renin-angiotensin-aldosterone system, RAAS, in relation to electrolyte balance in premature infants. Pediatr Res 1979; 13:817-20.

19 John EG. Problems related to potassium homeostasis in the newborn. Indian J Pediatr 1983;50:577-83.

20 Wright FS. Sites and mechanisms of potassium transport along the renal tubule. Kidney Int 1977;11:415-32.

21 Guignard JP, Torrado S, Mazouni M, Gautier E. Renal function in respiratory distress syndrome. J Pediatr 1976;88:845-50.

22 Stegner H, Leake RK, Palmer SM, Oakes G, Fisher DA. The effect of hypoxia on neurohypophyseal hormone release in fetal and maternal sheep. Pediatr Res 1984;18:188-99.

Correspondence to Dr T F Yeh, Division of Neonatology, Cook County Children's Hospital, 700 South Wood Street, Chicago, Illinois 60612, USA.

Received 31 January 1985 